\title{
Revendo conceitos: Uma resenha do livro "O mundo dos preconceitos" (Die Welt der Vorurteile, 2014) de Ágnes Heller
}

\author{
Reviewing conceptions: A book review of "The world of prejudices" (Die Welt der \\ Vorurteile, 2014) of Ágnes Heller
}

Josias Hilbert Hegele*

\begin{abstract}
Resumo
Resenha de: HELLER, Ágnes. Die Welt der Vorurteile: Geschichte und Grundlagen für Menschliches und Unmenschliches. Wien/Hamburg: Edition Konturen, 2014.
\end{abstract}

A filósofa húngara de origem judaica e sobrevivente da Shoah, Ágnes Heller, foi a sucessora de Hannah Arendt na cátedra de filosofia da New School for Social Research em Nova Iorque. O livro "O mundo dos preconceitos" (publicado originalmente em língua alemã, sob o título "Die Welt der Vorurteile") é fruto, no entanto, de aulas ministradas por Ágnes Heller no ano de 2013 na Universidade de Viena atuando, naquele ano, como professora visitante. O presente livro pode ser compreendido como um tratado filosófico a respeito do tema "preconceitos". Logo, no início, Heller define a sua tarefa filosófica que "consiste em demonstrar como preconceitos, num sentido moderno, surgiram a partir de um desenvolvimento social e que a crítica aos preconceitos responde a problemas da modernidade"1 (p. 7).

A obra está estruturada em sete capítulos. No primeiro capítulo, Heller analisa pressupostos ontológicos e antropológicos dos preconceitos. Heller compreende o surgimento de preconceitos, num sentido moderno, como a consequência de uma acentuada heterogenização das sociedades modernas. O segundo capítulo tematiza os prérequisitos sociais e psicológicos dos preconceitos. $\mathrm{O}$ diálogo com outros pensadores e outras pensadoras da filosofia, da sociologia e da psicologia, tais como: Niklas Luhmann, Hannah Arendt, Max Weber, Jan Assmann, Erich Fromm, Kierkegaard, Kant e Freud é

[Texto recebido em junho de 2017 e aceito em janeiro de 2018, com base na avaliação cega por pares realizada por pareceristas ad hoc]

* Pastor ordenado da Igreja Evangélica Luterana na Baviera (Alemanha). Graduado em Teologia (LudwigMaximilians-Universität de Munique), com estudos teológicos em São Leopoldo (Faculdades EST) e Göttingen (Georg-August-Universität). E-mail: josias.hilberthegele@elkb.de

1 As citações presentes nesta resenha são traduções do autor. 
algo marcante nesse capítulo. O terceiro capítulo se ocupa com a pergunta fundamental "Por que surgem preconceitos na modernidade?". Nesse contexto, "desenvolvimento" e "particularidade" são identificados como duas raízes do termo "preconceito". No quarto capítulo, são analisados preconceitos muito frequentes em diversas sociedades, a saber: preconceitos raciais, étnicos e religiosos. Especialmente o excurso "Sobre o conceito verdade" é digno de nota. Heller constata que vivemos na modernidade em diferentes esferas (p. ex. na esfera da religião, na esfera da arte, na esfera do direito etc.). Cada esfera tem, segundo Heller, o seu próprio conceito de verdade e este é, para cada esfera, específico e, portanto, não transferível para uma outra esfera. É, sem dúvida, questionável se esse ponto de vista pode ser compartilhado a partir de uma perspectiva teológica. No entanto, ele pode ser compreendido como um convite ao diálogo e a uma reflexão aprofundada. O quinto capítulo tem como título "O mal e o totalitarismo". De uma perspectiva teológica o quinto capítulo pode ser considerado o cerne do livro. Partindo de uma pergunta fundamental - e, ao mesmo tempo, muito complexa - "Como compreender Auschwitz e o holocausto?", a filósofa húngara responde:

A minha teoria é: O mundo moderno é, de certa maneira, marcado por uma ideologia que teve seu começo com a proclamação das palavras de Nietzsche "Deus está morto". Essa ideologia é marcada pela divinização dos seres humanos. Se Deus não existe, então o próprio ser humano tem que ser Deus [...] Eu não posso compreender o holocausto de outra maneira, exceto como algo religioso: Os nazistas queriam vencer Deus [...] Eu só posso entender o motivo do holocausto de uma maneira: Tratou-se de uma luta contra Deus, de uma luta pela divinização do comando" (p. 122s).

De maneira análoga ao quarto capítulo, são apresentados e refletidos criticamente, no sexto capítulo, preconceitos como "Preconceitos de classe, preconceitos contra mulheres e preconceitos sexuais". O sétimo e último capítulo é entitulado "Preconceitos filosóficos" e contém três subtemas: ciências naturais, preconceitos individuais e a pergunta pela identidade.

Caso o leitor e a leitora tenha o preconceito de que livros filosóficos são abstratos e distantes da realidade, esse livro pode ajudar na superação de tal preconceito. Através de uma linguagem simples e com vários exemplos do cotidiano, da literatura e da música, o livro de Ágnes Heller oportuniza uma leitura agradável e, ao mesmo tempo, com padrão acadêmico. A teologia em toda a sua história sempre fez bem em buscar o diálogo com a filosofia. O diálogo teológico com a filosofia de Ágnes Heller tem sido ainda vago. O livro "O mundo dos preconceitos" oferece um bom material para um diálogo interdisciplinar frutífero. Não por último, pois a fé cristã está centrada na figura de Jesus Cristo que, segundo os relatos bíblicos, muitas vezes questionou e superou preconceitos (p. ex. contando a parábola do bom samaritano, na qual há uma tematização do preconceito 
étnico-religioso presente na época). A leitura de "O mundo dos preconceitos" pode ajudar a rever conceitos e a relembrar algo fundamental: Deus não faz acepção de pessoas, bem como Pedro reconhece no seu encontro com Cornélio: "Então, falou Pedro, dizendo: Reconheço, por verdade, que Deus não faz acepção de pessoas; pelo contrário, em qualquer nação, aquele que o teme e faz o que é justo lhe é aceitável" (At 10:34s). 